\title{
Socioeconomic Characteristics of Pradhan Mantri Krishi Sinchayee Yojana (PMKSY) Beneficiaries
}

\author{
Pratibha Yadav, Seema Naberia* and Dharmanand Verma
}

Department of Extension Education, College of Agriculture, JNKVV, Jabalpur (M.P.), India

*Corresponding author

\section{A B S T R A C T}

Keywords

PMKSY

beneficiaries,

Profile, Socio-

economic

Article Info

Accepted:

05April 2020

Available Online:

10 May 2020

\begin{abstract}
The present study was conducted to investigate the profile characteristics of Pradhan Mantri Krishi Sinchai Yojana (PMKSY) beneficiaries of district Jabalpur (M.P.). One hundred and twenty beneficiaries from Majholi and Jabalpur blocks were selected on the basis of availability of highest beneficiaries of the PMKSY scheme. The study revealed that higher percentage of PMKSY beneficiaries were middle aged, educated up to high school, had medium size of land holding. Majority of the PMKSY beneficiaries were found different medium attributes viz. farming experience, extension contact, mass media exposure, social participation, innovativeness, economic motivation and risk orientation.
\end{abstract}

\section{Introduction}

Government of India introduced Pradhan Mantri Krishi Sinchayi Yojana in the Year 2015. PMKSY was formulated to expand cultivable area under assured irrigation, to reduce water wastage and to improve water use efficiency in

PMKSY is creating protective irrigation by harnessing rain water at micro level through Jal Sanchay and Jal Sinchan. PMKSY has been implemented with an outlay of Rs. 50,000 crore in five years (2015 to 2020).
The net agricultural area of India is 200.8 million hectare, out of which only 95.8 million hectare i.e. $48 \%$ of area is covered under irrigation and 52\% area is not covered under irrigation i.e. unirrigated area. Farmers in India majorly depending on rainfall for irrigation and it leads to less production output from farms.

In order to enhance farm Income by increasing productivity and motivating farmers to invest more in farming, Pradhan Mantri Krishi Sinchayi Yojana (PMKSY) was introduced. PMKSY ensures protective 
irrigation to all agricultural farms in the country Har Khet Ko Paani (Water for every field) to produce Per drop More Crop and bringing much desired rural prosperity.

In this connection a study is conducted to understand the various socio-economic characteristics of the beneficiaries. The outcome will be useful on redesign the further out reach of the programme.

\section{Materials and Methods}

The study was conducted in Jabalpur district of Madhya Pradesh. The Jabalpur district comprises of seven blocks out of which Jabalpur and Manjholi were purposively selected on account of having maximum number of beneficiaries under PMKSY as compared to other blocks.

Three villages from each block were selected for the study. Total 120 PMKSY beneficiaries were selected randomly as respondents. The data collection was done by the use of interview schedule through personal interview. Data were analyzed with help of suitable statistical tools.

\section{Results and Discussion}

The socio-economic, communicational \& psychological characteristics of Pradhan Mantri Krishi Sinchai Yojana (PMKSY) beneficiaries of district Jabalpur (M.P.) were analyzed and presented in Table-1.

Table.1 Distribution of the PMKSY beneficiaries according to their profile attributes

\begin{tabular}{|c|c|c|c|c|}
\hline S.No. & Variable & Attributes & Frequency & Percentage \\
\hline \multirow[t]{3}{*}{1.} & \multirow[t]{3}{*}{ Age } & Young (Up to 35 years) & 27 & 22.50 \\
\hline & & Middle (36-55 years) & 52 & 43.34 \\
\hline & & Old (56 years and above) & 41 & 34.16 \\
\hline \multirow[t]{7}{*}{2.} & \multirow{7}{*}{ Education } & Illiterate & 3 & 2.50 \\
\hline & & Only read and write & 5 & 4.17 \\
\hline & & Primary school & 13 & 10.83 \\
\hline & & Middle school & 16 & 13.33 \\
\hline & & High school & 41 & 34.17 \\
\hline & & Higher Secondary & 31 & 25.83 \\
\hline & & Graduation and above & 11 & 9.17 \\
\hline \multirow[t]{4}{*}{3.} & \multirow[t]{4}{*}{ Farm Size } & Marginal farmer (Up to 1 ha ) & 12 & 10.00 \\
\hline & & Small farmer (1.01 to $2 \mathrm{ha}$ ) & 38 & 31.67 \\
\hline & & Medium farmer (2.01 to 4 ha) & 52 & 43.33 \\
\hline & & Large farmer (more than 4 ha) & 18 & 15.00 \\
\hline \multirow[t]{3}{*}{4.} & \multirow[t]{3}{*}{ Farming Experience } & Low & 36 & 30.00 \\
\hline & & Medium & 45 & 37.50 \\
\hline & & High & 39 & 32.50 \\
\hline \multirow[t]{3}{*}{5.} & \multirow[t]{3}{*}{ Extension Contact } & Low & 31 & 25.84 \\
\hline & & Medium & 50 & 41.66 \\
\hline & & High & 39 & 32.50 \\
\hline
\end{tabular}




\begin{tabular}{|c|c|c|c|c|}
\hline \multirow[t]{3}{*}{6.} & Mass media Exposure & Low & 36 & 30.00 \\
\hline & & Medium & 54 & 45.00 \\
\hline & & High & 30 & 25.00 \\
\hline \multirow[t]{3}{*}{7.} & \multirow[t]{3}{*}{ Social Participation } & Low & 31 & 25.83 \\
\hline & & Medium & 54 & 45.00 \\
\hline & & High & 35 & 29.17 \\
\hline \multirow[t]{3}{*}{8.} & \multirow[t]{3}{*}{ Innovativeness } & Low & 34 & 28.33 \\
\hline & & Medium & 45 & 37.50 \\
\hline & & High & 41 & 34.17 \\
\hline \multirow[t]{3}{*}{9.} & \multirow[t]{3}{*}{ Economic Motivation } & Low & 23 & 19.17 \\
\hline & & Medium & 58 & 48.33 \\
\hline & & High & 39 & 32.50 \\
\hline \multirow[t]{3}{*}{10.} & \multirow[t]{3}{*}{ Risk Orientation } & Low & 34 & 28.33 \\
\hline & & Medium & 55 & 45.83 \\
\hline & & High & 31 & 25.84 \\
\hline
\end{tabular}

Innovativeness is very important trait of an individual, in the study it was found that, 37.50 per cent of the PMKSY beneficiaries had medium level of innovativeness followed by high (34.17\%) and low (28.33\%) level of innovativeness. Economic motivation of the PMKSY beneficiaries were assessed and found that 48.33 per cent had medium economic motivation followed by 32.50 per cent had high and 19.17 per cent had low economic motivation. Table indicated that, 45.83 per cent PMKSY beneficiaries had medium risk orientation followed by low (28.33\%) and high $(25.84 \%)$ risk orientation respectively. This finding is similar with finding of Adeniyi (2014), Adhikari (2007), Grace et al., (2015), Ninama (2012), Radhika (2007), Raina et al., (2016), Rasouliazar et al., (2011), Sandesh (2004), Saxena et al., (2000).

The study revealed that the profile of the PMKSY beneficiaries had higher percentage of PMKSY beneficiaries were middle aged, educated up to high school, had medium size of land holding. Majority of the PMKSY beneficiaries were found different medium attributes viz. farming experience, extension contact, mass media exposure, social participation, innovativeness, economic motivation, and risk orientation. The findings will definitely facilitate to policy makers as well as extension agents in formulating different strategies suited for appropriate clientele.

\section{References}

Adeniyi, O.A. 2014. Marginal effects of farmers' age on their irrigation technology adoption in poverty reduction in Kwara state. Global Journal of Interdisplinary Social Sciences. 3(4): 53-56.

Adhikari G. 2007. Knowledge and adoption behavior of rice growers in Hohangabad district of M.P. M.Sc. (Ag) Thesis ,JNKVV Jabalpur.

Grace EP and Msoffe. 2015. Access and use of poultry management information selected rural area of Tanzania. Ph.D. (Information science) Thesis University of South Africa.

Ninama BS. 2012. Information management behaviour in relation to dairy farming among the farmers. Unpublished M.Sc. (Ag.) Thesis of CoA Rewa 
(M.P.)

Radhika, M. 2007. An analytical study on impact of Andhra Pradesh Micro Irrigation Project in Mahaboobnagar district of Andhra Pradesh. M.Sc (Ag.) Thesis. Acharya N.G. Ranga Agricultural University, Hyderabad.

Raina V, Bhushan B, Bakshi P and Khajuria S. 2016. Entrepreneurial Behaviour of Dairy Farmers Journal of Animal Research:6(5):947-953.

Rasouliazar, S and Saeidfeli. 2011. Effective factors on discontinuance of sprinkler irrigation systems among farmers in

\section{How to cite this article:}

Pratibha Yadav, Seema Naberia and Dharmanand Verma. 2020. Socioeconomic Characteristics of Pradhan Mantri Krishi Sinchayee Yojana (PMKSY) Beneficiaries. Int.J.Curr.Microbiol.App.Sci. 9(05): 814-817. doi: https://doi.org/10.20546/ijcmas.2020.905.090
West Azerbaijan province of Iran. Journal of American Science. 7(2):584-590.

Sandesh HM. (2004). A study of Kannada Farm magazine readers in Karnataka, M.Sc. (Agric) Thesis, University of Agricultural Sciences, Dharwad

Saxena KK and Singh RL. (2000). Adoption of organic farming practices by farmers of Malwa region. Maharashtra Journal of Extension Education.19: 53-55 